\begin{tabular}{|l|l|}
\hline JURNAL ABDI MASYA & $\begin{array}{l}\text { Volume 1 Nomor 1 } \\
\text { November 2020 } \\
\text { pp 27-34 } \\
\text { E-ISSN : dalam proses }\end{array}$ \\
Website: https://jurnal.sttw.ac.id/index.php/abma/about \\
\hline
\end{tabular}

\title{
PEMBUATAN ALAT CUCI TANGAN PORTABEL DALAM UPAYA MENCEGAH PENULRAN COVID-19 DI KELURAHAN SANGKRAH, PASAR KLIWON, KOTA SURAKARTA
}

\section{MANUFACTURE OF PORTABLE HAND WASHER TO PREVENT COVID-19 IN SANGKRAH VILLAGE, PASAR KLIWON, SURAKARTA CITY}

Agung Supriyanto ${ }^{1 *}$, Muhammad Vendy Hermawan ${ }^{2)}$

1), 2) Program Studi Teknik Mesin, Sekolah Tinggi Teknologi Warga, Surakarta, Indonesia *Email : agungatw@yahoo.com

\begin{abstract}
ABSTRAK
Perhatian dunia saat ini sedang fokus pada penanganan wabah virus COVID-19 yang sudah dinyatakan sebagai pandemi pada awal Januari 2020. Sebagian besar negara sudah menerapkan karantina wilayah untuk mencegah terjadinya penyebaran virus yang cepat. Indonesia sendiri tengah berupaya untuk mengatasi masalah penularan wabah COVID-19 dengan menerapkan social distancing bagi warganya. Kelurahan Sangkrah adalah salah satu wilayah di kota Surakarta yang sudah dinyatakan sebagai daerah zona merah penyebaran COVID-19 oleh Bapak Walikota. Terdapat 2 kasus positif COVID-19 pada bulan April 2020 di wilayah ini. Dengan pertimbangan tersebut, perlu dilakukan penanganan serius guna memutus penyebaran virus COVID-19. Salah satu cara yang dapat dilakukan adalah dengan menambahkan sarana tempat cuci tangan kepada masyarakat Kelurahan Sangkrah. Cuci tangan dengan sabun pada air mengalir terbukti lebih ampuh membunuh virus jika dibandingkan dengan hanya menggunakan cairan hand sanitiser. Tempat cuci tangan portabel yang didedikasikan untuk warga kelurahan Sangkrah berguna untuk memutus mata rantai penyebaran COVID-19. Alat cuci tangan ini telah digunakan dengan baik oleh warga masyarakat Kelurahan Sangkrah. Setelah mendapat penyuluhan tentang pentingnya cuci tangan, berdampak pada peningkatan kesadaran masyarakat untuk cuci tangan.
\end{abstract}

Kata Kunci : COVID-19, Tempat cuci tangan portabel, Sangkrah.

Submit : 8 September 2020 , Accepted: 5 oktober 2020

Published: 24 November 2020

\section{PENDAHULUAN}

Kelurahan Sangkrah adalah sebuah wilayah di Kota Solo.Terletak di bagian timur Kota Solo, dengan batas Kali Pepe di selatan dan Bengawan Solo di sebelah timur. Sangkrah memiliki stasiun kereta yang dikelilingi oleh pasar sebagai pusat ekonomi warga. Jumlah penduduk di kelurahan Sangkrah pada tahun 2020 adalah 11.326 populasi, dengan junlah keluarga mencapai 3.238 KK. Kelurahan Sangkrah memiliki luas wilayah 46,01 km² dengan kepadatan penduduk mencapai $12.220 \mathrm{jiwa} / \mathrm{km}^{2}$. Kepadatan penduduk di wilayah Sangkrah yang tergolong tinggi menyebabkan potensi penularan penyakit menular sangat besar. Terlebih, pada bulan April 2020 terdapat 1 warga yang meninggal akibat terpapar Covid-19 seusai mudik dari kota Surabaya. Hal ini membuat wilayah Sangkrah ditetapkan sebagai zona merah Covid-19.Salah satu cara efektif untuk memutus mata rantai penyebaran Covid-19 adalah dengan sering mencuci tangan dengan sabun. Keterbatasan sarana prasarana tempat cuci tangan di wilayah Sangkrah menjadi masalah tersendiri yang harus segera diselesaikan.

Virus Corona adalah sebuah keluarga virus yang ditemukan pada manusia dan hewan. Sebagian virusnya dapat menginfeksi manusia serta menyebabkan berbagai penyakit, mulai dari penyakit umum seperti flu, hingga penyakit-penyakit yang lebih fatal, 
seperti Middle East Respiratory Syndrome (MERS) dan Severe Acute Respiratory Syndrome (SARS). Corona Virus Disease 19 (Covid-19) adalah varian virus corona yang muncul pada akhir tahun 2019 di kota Wuhan, Cina [1]. Penyebarannya begitu cepat di seluruh dunia, hingga pada bulan Februari 2020 WHO menetapkan sebagai pandemi dunia.

Penularan virus corona bisa terjadi melalui berbagai hal, antara lain droplets atau tetesan cairan yang berasal dari batuk dan bersin, kontak pribadi seperti menyentuh dan berjabat tangan, menyentuh benda atau permukaan dengan virus di atasnya, kemudian menyentuh mulut, hidung, atau mata sebelum mencuci tangan dan kontaminasi tinja (jarang terjadi).

Sebuah studi terbaru menunjukkan potensi penularannya melalui udara. Ketika seseorang batuk atau bersin dan mengeluarkan cairan mengandung virus, berpotensi akan menyebar ke udara dan bisa langsung masuk ke tubuh orang lain jika berada dalam posisi berdekatan.

Covid-19 dapat ditularkan melalui tetesan, atau sedikit cairan, sebagian besar melalui bersin atau batuk [2]. Para peneliti menemukan bahwa virus itu juga bisa bertahan dalam jangka waktu tertentu di udara dan menempel di permukaan benda, bergantung pada beberapa faktor, seperti panas dan kelembapan [3].

Hingga saat ini belum ditemukan vaksin untuk mencegah seseorang terinfeksi Virus Corona. Cara terbaik untuk melindungi diri kita adalah dengan menghindari kondisi atau tempat yang berpotensi terpapar virus tersebut. Sebuah lembaga pencegahan penyakit di Amerika, Center for Disease Control and Prevention (CDC) menyarankan sejumlah halhal di bawah ini untuk mencegah penyebaran penyakit pernapasan, yaitu tinggal di rumah jika sakit, tutupi mulut saat batuk dan bersin dengan menggunakan tisu, perbanyak membersihkan barang-barang serta perabotan di rumah, perbanyak cuci tangan menggunakan air dan sabun paling tidak selama 20 detik, terutama sebelum makan dan setelah buang ingus, batuk atau bersin. Jika air dan sabun tidak tersedia, gunakanlah pembersih tangan alkohol dengan kandungan alkohol sebanyak minimal 60\% [4]. Cuci tangan tanpa menggunakan sabun tidak akan mampu membunuh kuman yang ada di telapak tangan [5]. Hindari menyentuh wajah sebelum cuci tangan dan jangan kontak dekat dengan orang-orang sakit

Wabah virus corona masih terjadi di Indonesia. Kasus-kasus infeksi Covid-19 telah dikonfirmasi terjadi di seluruh provinsi di Indonesia. Salah satu cara untuk mematikan virus Covid-19 adalah dengan mencuci tangan menggunakan sabun [6]. Sel virus Covid-19 dibungkus oleh lapisan lemak yang sangat tipis. Lapisan lemak ini dapat dengan mudah hancur jika terkena sabun [7]

\section{METODE}

Secara garis besar, kekegiatan pengabdian ini dibagi menjadi beberapa tahapan yang sistematis.

a) Identifikasi Permasalahan Mitra

Beberapa hal yang menjadi permasalahan mitra yang perlu diberikan solusinya melalui penyuluhan dan pembuatan produk antara lain kesadaran penduduk yang masih kurang dalam menerapkan pola hidup sehat serta kurangnya ketersediaan fasilitas umum berupa tempat cuci tangan di lokasi-lokasi yang dianggap sebagai titik fokus kegiatan penduduk seperti kantor kelurahan, pasar, pintu masuk kampung dan lokasi strategis lainnya.

b) Kerangka Pemecahan Masalah

Memberikan pemahaman kepada masyarakat akan pentingnya menerapkan hidup sehat. Memberikan bantuan berupa alat cuci tangan portabel untuk menunjang kebutuhan sarana kebersihan di lingkungan masyarakat.

c) Program solutif untuk pemecahan masalah 
Sesuai dengan identifikasi masalah yang ada, tim menawarkan solusi berupa penyuluhan tentang pentingnya membudayakan cuci tangan bagi masyarakat khususnya di ruang-ruang publik serta pembuatan produk berupa alat cuci tangan portable bagi masyarakat di lingkungan wilayah Kelurahan Sangkrah.

d) Pelakasanaan Program

Pelaksanaan program dilakukan dengan mengacu pada solusi yang harus dilakukan, target pelaksanaan program dan jumlah titik lokasi yang menjadi prioritas. Untuk pembuatan alat cuci tangan ini, langkah awal dimulai dengan pembuatan desain. Setelah desain siap maka dilakukan pembuatan produk.

e) Monitoring

Keberhasilan program ini perlu dilakukan dengan kegiatan monitoring atau pengawasan yang dilaksanakan secara terprogram dan periodik.Tujuannya adalah agar alat yang di buat benar-benar bermanfaat bagi masyarakat. Serta untuk mengetahui kelebihan dan kekurangan produk yang dibuat sebagai bahan untuk penyempunaan.

f) Evaluasi

Evaluasi dilakukan terhadap keluhan masyarakat atas penggunaan produk agar kedepan dapat lebih disempurnakan.

\subsection{Bahan}

Kegiatan ini menggunakan bahan untuk pembuatan alat cuci tangan portabel yaitu :
a) Bak cuci tangan ukuran $50 \mathrm{~cm}$ stainless steel :7 buah
b) Baut gipsum $4 \mathrm{~cm}: 30 \mathrm{pcs}$
c) Penampung air plastik 25 Liter : 7 buah
d) Sambungan pipa $1 / 2$ inchi : 24 buah
e) Besi 30x30x1.4 mm : 14 batang
f) Besi L $28 \times 4$ : 5 batang
g) Thinner SP $306 \quad$ : 1 kaleng
h) DPL PLST Alfagloss 170 gram : 1 kaleng
i) Keran air 1/2 inch : :7 buah
j) Lastok $2.0 \quad: 1$ dus

\subsection{Alat}

Adapun alat yang dipergunakan untuk membuat alat cuci tangan portabel adalah :
a) Gergaji cut off
b) Las litrik
c) Gerinda
d) Mesin bor

\section{HASIL DAN PEMBAHASAN}

Desain alat cuci tangan ini dibuat dengan memperhatikan kemudahan dalam penggunaan dan dengan perawatan yang mudah. Gambar desain dan ukuran spesifik dari rangka alat cuci tangan ditampilkan pada Gambar 1 dan Gambar 2. 
AbMa (Jurnal Abdi Masya): Vol. 1, No. 1, pp 27-34 Agung Supriyanto, Muhammad Vendy Hermawan. (๐ 2020

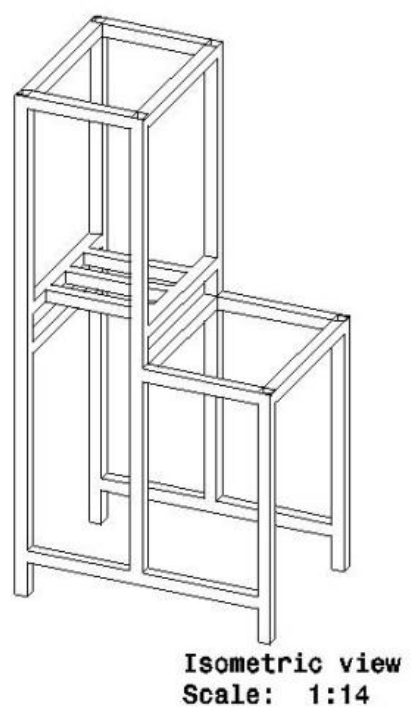

Gambar 1. Desain 3-dimensi rangka alat cuci tangan portabel
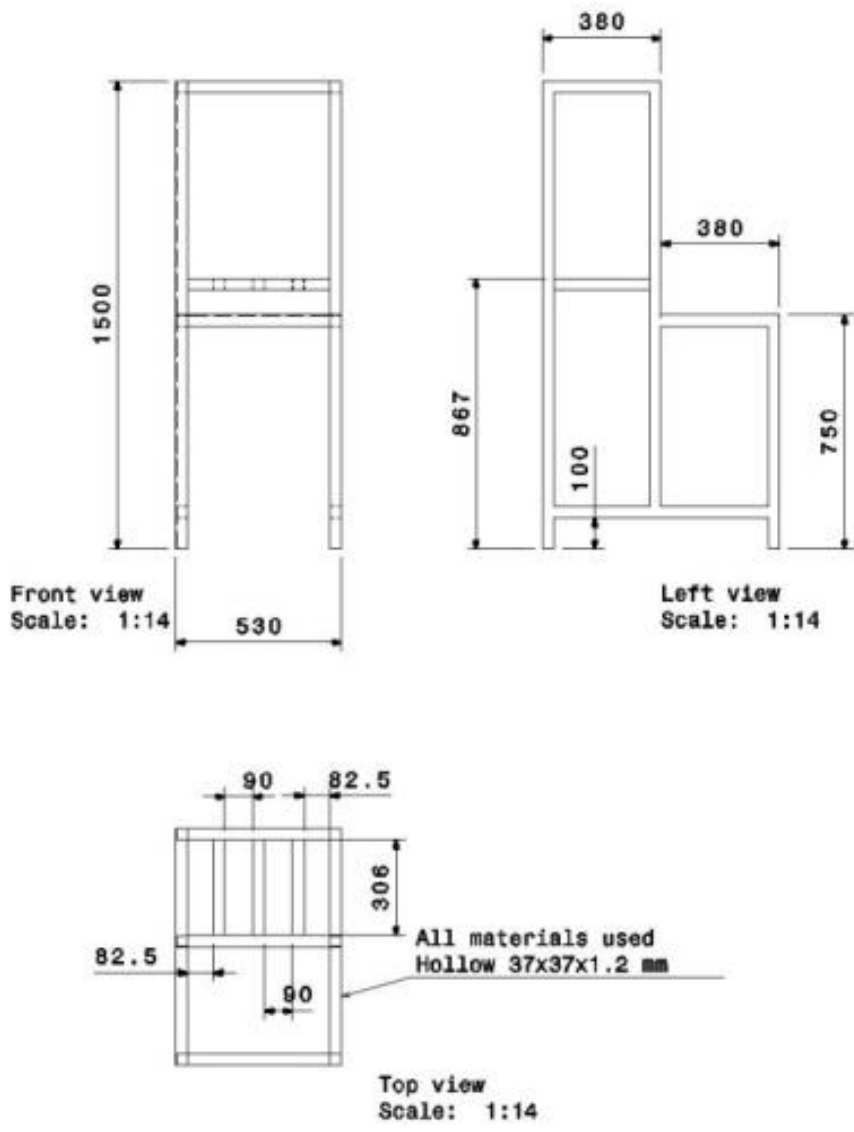

Gambar 2. Dimensi rangka tempat cuci tangan 
Proses pembuatan alat cuci tangan dilakukan di bengkel las rekanan, dengan peran serta dosen dan mahasiswa Akademi Teknologi Warga Surakarta. Adapun proses pembuatan ditampilkan pada Gambar 3 dan Gambar 4.

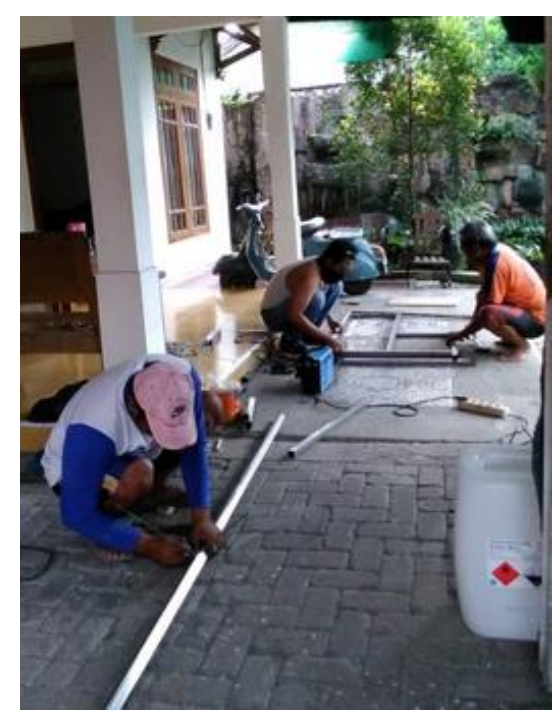

Gambar 3. Proses pengukuran dan pemotongan material

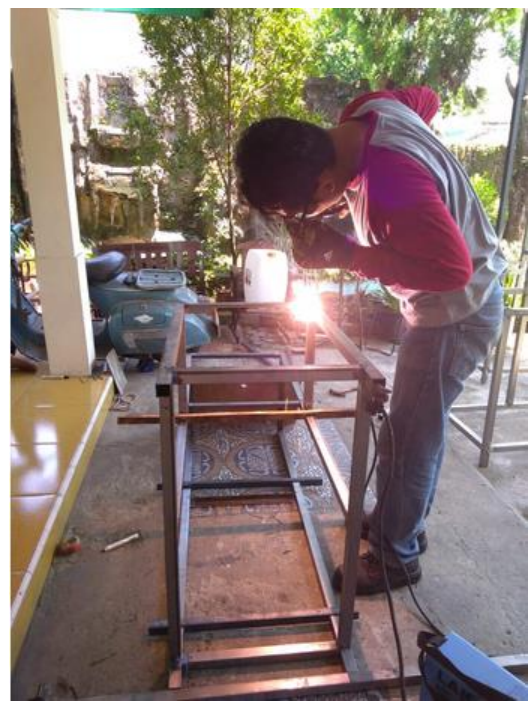

Gambar 4. Proses pengelasan kerangka

Metode yang dilakukan untuk membuat kerangka adalah dengan pengelasan. Karena dinilai metode ini lebih cepat dan efisien. Hasil pengelasan juga cukup kuat untuk menahan beban yang akan diterima oleh rangka alat cuci tangan. Setelah rangka alat cuci tangan selesai, selanjutnya adalah menginstall aksesoris tambahan lain seperti tabung penampung air, keran, bak cuci tangan dan pipa. Kerangka yang sudah jadi ditampilkan pada Gambar 5, sedangkan produk yang sudah jadi ditampilkan pada Gambar 6. 


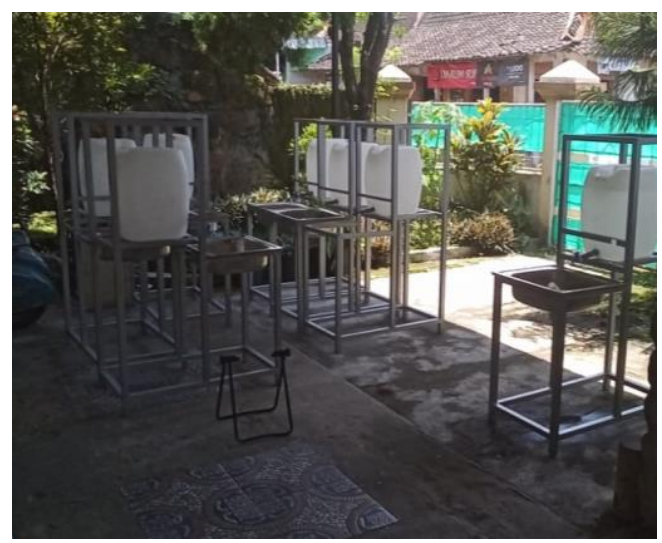

Gambar 5. Kerangka alat cuci tangan

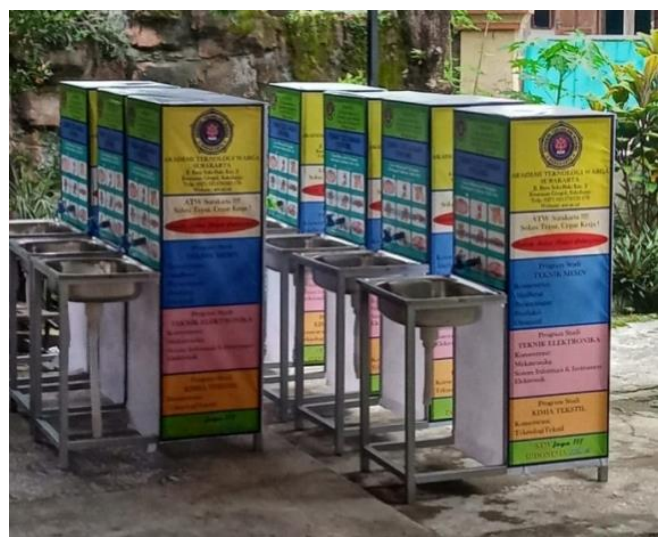

Gambar 6. Produk akhir alat cuci tangan portabel

Alat cuci tangan yang sudah jadi selanjutnya didistribusikan ke beberapa lokasi di kelurahan Sangkrah, kecamatan Pasar Kliwon, Surakarta. Informasi tentang titik-titik lokasi penempatan alat cuci tangan portabel disajikan pada Tabel 1. Gambar 7 menampilkan proses serah terima yang dilakukan oleh perwakilan dosen Sekolah Tinggi Teknologi Warga Surakarta bersama mahasiswa yang diterima langsung oleh Lurah setempat.

Tabel 1. Lokasi penempatan alat cuci tangan

\begin{tabular}{lll}
\hline No & \multicolumn{1}{c}{ Tempat } & \multicolumn{1}{c}{ Aktifitas } \\
\hline $\mathbf{1}$ & Perempatan RT 02 & $\begin{array}{l}\text { pagi hari : aktifitas warung nasi } \\
\text { liwet, jenang } \\
\end{array}$ \\
& & sore hari : wedangan \\
$\mathbf{2}$ & Perempatan RT 05 & mushola, toko kelontong \\
$\mathbf{3}$ & Kantor kelurahan sangkrah & kantor kelurahan \\
$\mathbf{4}$ & RT 07 & balai RT, koperasi \\
$\mathbf{5}$ & RT 06 & taman bermain \\
$\mathbf{6}$ & RT 04 & warung, pos kamling \\
$\mathbf{7}$ & RT 05 & warung, pos kamling \\
\hline
\end{tabular}




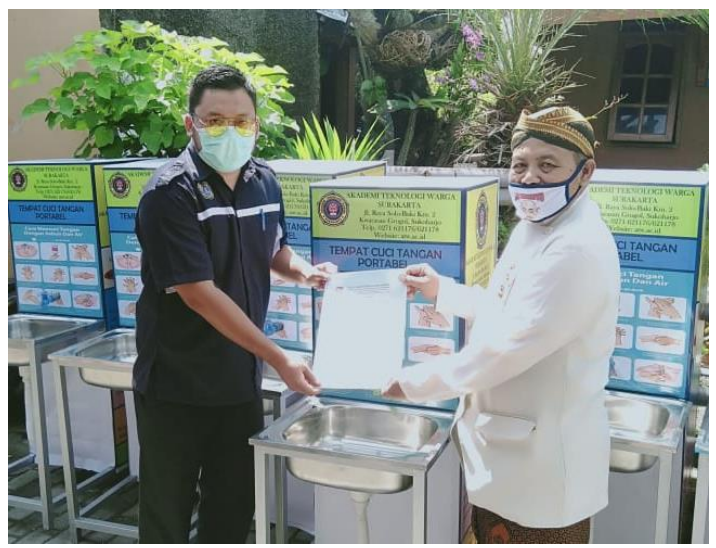

Gambar 7. Serah terima alat cuci tangan portabel

Peletakan alat cuci tangan portabel ke titik lokasi yang sudah ditentukan mendapat bantuan dari warga setempat dan staf kelurahan. Gambar 8 menampilkan beberapa titik lokasi penempatan alat cuci tangan portabel.
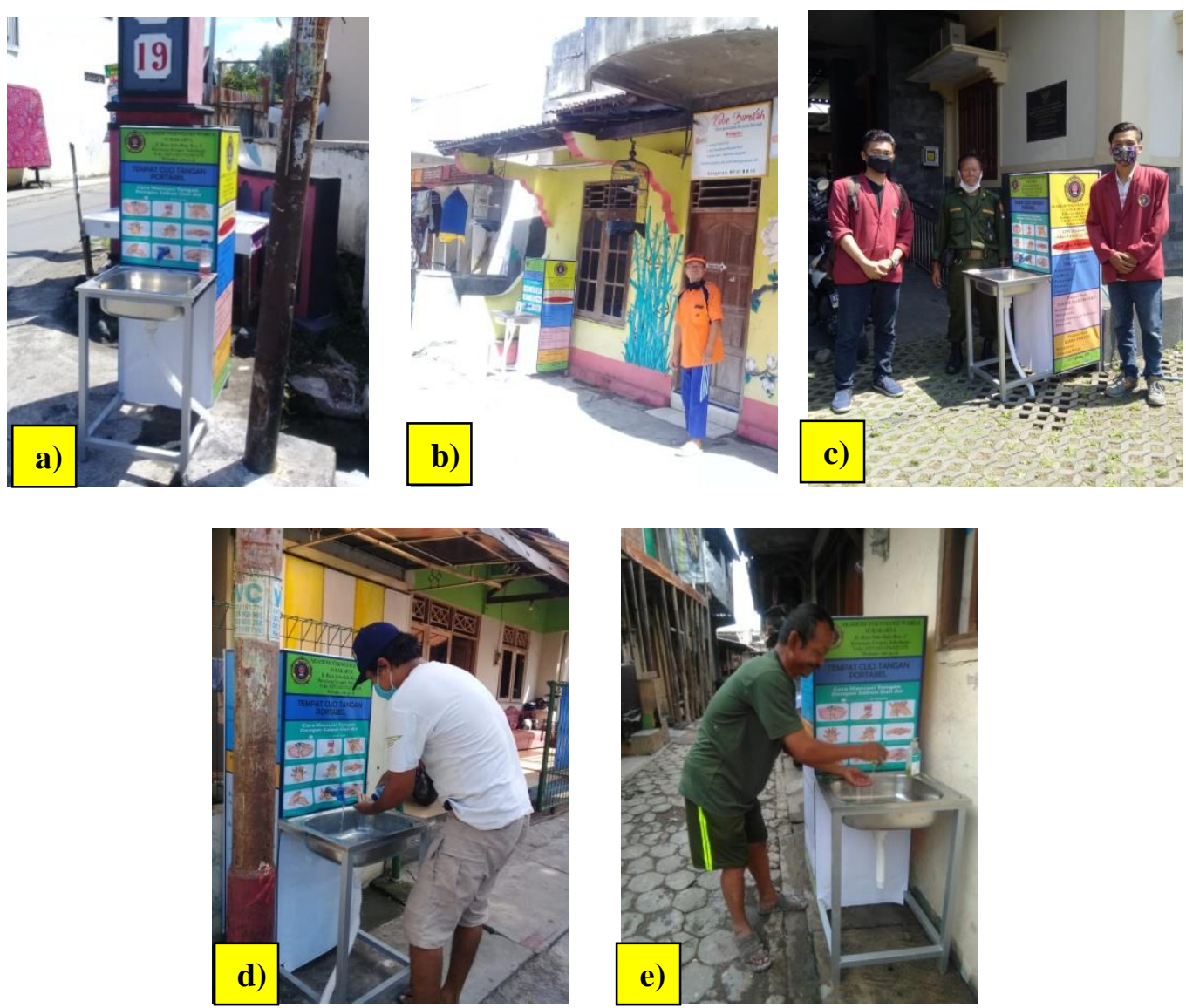

Gambar 8. Lokasi penempatan alat cuci tangan portabel, a) Perempatan RT 02, b)RT 06,

c) Kantor kelurahan Sangkrah, d) perempatan RT 05, e) RT 07

\section{KESIMPULAN}

Setelah melakukan evaluasi, maka kesimpulan dari kegiatan pengabdian ini adalah: 
a) Alat yang dibuat dapat digunakan oleh warga untuk aktifitas cuci tangan dalam upaya mencegat penularan penyakit covid- 19 .

b) Setelah mendapat penyuluhan warga mempunyai kesadaran untuk selalu sering cuci tangan.

c) Alat yang dibuat masih perlu dilakukan penyempurnaan, terutama pada sistem keran. Warga masih menyentuh keran sebelum mencuci tangan untuk mengalirkan air, hal ini menyebabkan keran terkontaminasi virus dari tangan yang belum bersih.

\section{DAFTAR PUSTAKA}

[1] D. Paraskevis, E. G. Kostaki, G. Magiorkinis, G. Panayiotakopoulos, G. Sourvinos, and S. Tsiodras, "Full-genome evolutionary analysis of the novel corona virus (2019-nCoV) rejects the hypothesis of emergence as a result of a recent recombination event," Infect. Genet. Evol., vol. 79, no. January, p. 104212, 2020.

[2] A. Dighe, T. Jombart, M. D. Van Kerkhove, and N. Ferguson, "A systematic review of MERS-CoV seroprevalence and RNA prevalence in dromedary camels: Implications for animal vaccination," Epidemics, vol. 29, no. March, p. 100350, 2019.

[3] M. G. Manoj, M. K. Satheesh Kumar, K. T. Valsaraj, C. Sivan, and S. K. Vijayan, "Potential link between compromised air quality and transmission of the novel corona virus (SARS-CoV-2) in affected areas.," Environ. Res., p. 110001, 2020.

[4] Kementerian Kesehatan Republik Indonesia, "Peraturan menteri kesehatan Republik Indonesia Nomor 27 Tahun 2017 Tentang Pedoman PPI. Pencegahan danPengendalian Infeksi (PPI)." Jakarta, 2017.

[5] C. O. Hunt and Z. Morawska, "Are your hands clean? Pollen retention on the human hand after washing," Rev. Palaeobot. Palynol., vol. 280, p. 104278, 2020.

[6] Sugihantoro. A, "Pedoman Kesiapsiagaan Menghadapi Coronavirus Disease (COVID-19)." Direktorat Jenderal Pencegahan dan Pengendalian Penyakit, Kementerian Kesehatan Republik Indonesia., 2020.

[7] World Health Organization (WHO)., "Laboratory testing for 2019 novel coronavirus (2019-nCoV) in suspected human cases," Medical world, vol. 75, no. 23. pp. 620-622, 2020. 